ISAHP Article: Mu, Saaty/A Style Guide for Paper Proposals To Be Submitted to the International Symposium of the Analytic Hierarchy Process 2014, Washington D.C., U.S.A.

\title{
Determination of Establishing Factoring Company's Locations by AHP Analysis: Implementations of 3 Major Cities in Turkey
}

\author{
Mehmet ILHAN \\ Faculty of Economics and \\ Administrative Sciences \\ University of Usak \\ Usak, TÜRKIYE \\ E-mail: mehmet.ilhan@usak.edu.tr \\ Sadık KARAOĞLAN \\ Faculty of Economics and \\ Administrative Sciences \\ University of Aydin \\ Aydın, TÜRKIYYE \\ E-mail: sadik.karaoglan@adu.edu.tr \\ Melek ILHAN \\ Faculty of Economics and \\ Administrative Sciences \\ University of Usak \\ Usak, TÜRKIYE \\ E-mail: melek.akkurt@usak.edu.tr
}

\begin{abstract}
All that exists in the world is in a process of changing and developing. Especially humans, they are the ones most affected by this changing process. The human knowledge, wants, wishes, dreams, goals, needs and whatever he adires to know has affected his environment. As well as technology developments, countries' situations, economics and finance, the bank and insurance systems, law systems and company's all are developed. Sometimes these developments can't be enough to answer or solve the problems of humans. As a result humans gave importance to developments of new methods. One of this is Factoring Companies. In the years 1980 it entered into Turkish market and it expanded after the years 2000.The main purpose of this work isn't the expanding business enterprise, the factoring companies cash method activity, examining the application or the risks taken for profits(every risk has its cost price) to transfer the days of paying debts, the factoring and insurance companies' comparison or the business' guaranty or the analyzing financing services' advantages. The main aim of this work is the factoring companies' plus the technology's development's establishment in Turkey's 3 biggest provinces to determinate the most affective factor AHP's analyzation.
\end{abstract}

The key words: Developing Economic and Financial Systems, Factoring Company, AHP's analyzation, Technology. 
IJAHP Article: Mu, Saaty/A Style Guide for Paper Proposals To Be Submitted to the International Symposium of the Analytic Hierarchy Process 2014, Washington D.C., U.S.A.

\section{Introduction}

In now days especially technology's development along with this development the coming up of markets, economic systems and financial systems' changing and developing and expansions are parallel to the changes of the Turkish Factoring companies. In its first establishment site, the most important action was finding out what the Factoring company is or finding where to place the new branch if opened, according to what the determination is and determining to find what it is for. The technology developments' aim is to outrage the effects on the Factoring companies working radius. Because, there's need for the Factoring companies in order to proof the companies' competition bareness and continuousness.

\section{Literature Review}

In the world's market the factoring companies started expanding in the years after 1990.As for in Turkey it expanded more after the years 2000.In Turkey, there are articles and thesis about factoring companies' law structure, the factoring's contracts' structure and Institution's conditions. The Factoring's action and Turkey's Factoring Sector in the Reel Sector's financing Sector, Comparison Anilisation of the Factoring and Credit Insurance Operations, A method as an Exportation Financing Factoring, Factoring and Financing Companies Statute General Point Of View are some of these articles. As anew point of view, estimating the establishment area of the factoring is one of the most important topics.

\section{Hypotheses/Objectives}

Factoring companies establishment area, Industrial Organizations' area's largeness and number, Trade size, population density, the distance of factoring companies to the customers and number of factoring companies in the province. All these are intended to be output with the most affective element, the Factor's AHP analyzation

\section{Research Design/Methodology}

At the end of this process, the establishment area in Turkey's three biggest provinces would be done by the help of the most effective Factor the AHP analyzation. The Factor's finances would finally be aware of all the factors. In the opening of the next branches or the Factoring financing in these 3 biggest provinces wouldn't require waste of time in analyzing but even it would be aware of arranging from the most effective to the least effective one. 
IJAHP Article: Mu, Saaty/A Style Guide for Paper Proposals To Be Submitted to the International Symposium of the Analytic Hierarchy Process 2014, Washington D.C., U.S.A.

\section{Data/Model Analysis}

In this process AHP model will be expanded and analyzed. Our foundation factors have been expanded by Turkey's economic condition as well as cultural characteristics. Our foundation factors are expanded in 5 elements. These are the industrial organization size and number, trade size, population density, the established factoring companies' nearness to the customers and the number of the factoring companies in the province. These will make up the the questions asked to the almost done factoring companies and determine the important points that will make up the matrix. When we look at the all points of view, our front intuition will be the size and number of the industrial area that is the most important factor in the considered establishment of the Factoring company in Turkey.

\section{Limitations}

In this process, the datum that concerns the three biggest provinces that we are examining will remain limited within those provinces. However, to make this process with more extensive datum that is to say that with the support of all Turkey's provinces and variety factoring companies more informative results can be gained.

\section{Conclusions}

The to be used AHP method will be applied as an informative characteristic to all institutions in the the world that want to establish the Factoring company in Turkey's 3 biggest provinces. This way feasibility expenses and wastage of time will be prevented till finance is seriously known and able to provide important thrifts. This is what we are in thought of.

\section{Key References}

Caliskan, S. (2010). Reel Sektörün Finansmanında Faktoring Rolü ve Türkiye'deki Faktoring Sektörü, Yüksek Lisans Tezi, İstanbul Üniversitesi, Sosyal Bilimler Enstitüsü, 44-75.

Cetin, A. C. ve Bitirak, A. İ. (2010) Banka Karlılık Performansının Analitik Hiyerarşi Süreci İle Değerlendirilmesi: Ticari Bankalar ile Katırım Bankalarında Bir Uygulama, 77-87

$\mathrm{Mu}$, E. (2006). A unified framework for site selection and business forecasting using ANP. Journal of Systems Science and Systems Engineering, 15(2), 178188.

Pellegrino O. (2012). Prediction of driver's workload by means of fuzzy techniques. Baltic Journal of Road and Bridge Engineering 7, 100-150 